\title{
Gender Resistance in Aladdin Disney Movie
}

\author{
Hadi Sampurna \\ \{hsampurna@yahoo.com\} \\ Universitas Jember, Indonesia
}

\begin{abstract}
Gender understanding is not only important for adults but also for children. Children are expected to learn about it from an early age. In connection with it, movies based on children literature can be fun and easy tools for gender learning. One of the children's stories that have been made in a movie is Aladdin. As a fantasy story, Aladdin movie can provide entertainment. On the other hand, through the movie, the children, especially the girls, are expected to learn about gender equity. According to this descriptive qualitative research, resistance could occur when the dominated is put in an unequal position. Those kinds of resistance are resistance to female domestication, to restrictions on participating in public affairs, to arranged marriage, and to education limitation.
\end{abstract}

Keywords: Gender, Resistance, Movie

\section{Introduction}

The Walt Disney Company or commonly known as Disney is a global entertainment and media company which was founded on October 16, 1923. The company was established by Walt Disney and Roy Oliver Disney under the name Disney Brothers Cartoon Studio. Its center is located in Burbank, California. As it is stated in its website, the mission of The Walt Disney Company is to entertain, inform and inspire people around the globe through the power of unparalleled storytelling, reflecting the iconic brands, creative minds and innovative technologies that make ours the world's premier entertainment company [1]. In line with its mission, Disney produces many movies with various genres. One of Disney's movies which is famous and mostly watched by families is Aladdin, produced in 2019.

Aladdin movie comes from folklore of The Arabian Nights. Aladdin tells a story of a poor young man who lived with his monkey friend named Abu. Aladdin then fell in love with Jasmine, the daughter of Sultan Agrabah. Jasmine was frustrated with her life because she was determined to marry a prince by her father. One day she left the palace alone. When she had a problem in the market, she met Aladdin who then helped her. Because of different classes and lives, Aladdin found it difficult to express his love for Jasmine. The way out was finally found when Aladdin got a magic lamp in which there was a genie that could grant three wishes. Unfortunately, Aladdin was not the only person who knew about the magic lamp. The evil royal advisor named Jafar also wanted to have the lamp to rule the Agrabah Empire and the world.

Movies are audio visual media. As audio-visual media, movies not only have good and clear abilities to display vivid images but also have sound that can make them more interesting and enjoyable. The ability owned by movies could attract the attention of people to watch. Combined with a compelling story, movies could tempt people to watch many times. This is what happens to Aladdin movie. The revenue achieved up to US \$ 1 billion shows large number of viewers of the movie [2]. 
As a folklore based-movie, Aladdin movie can become a medium that not only provides entertainment but can be a means of gender learning for people particularly children as well. When they are faced to a situation where gender inequity occurs, they can make resistance to get gender equity. Alcade [3] defines resistance as including overt and covert strategies for contesting what the affected person perceives as unjust or harmful. Resistance happens when condition faced by somebody puts them in an injustice situation. They could not get equal treatment like what others obtain. Continuous pressure will cause resistance to the group that presses. Moreover, theoretically informed by Marxist and neo-Marxist perspectives, resistance is framed in terms of class struggle [4]. Relating to gender studies, class struggle is seen as structural relations of antagonism between men and women. An emphasis on the historicity of gender and sexual identities broadens the meaning of 'gender resistance' to include resistance to the naturalizing operations of discursive practices [5]. Gender belief systems in society state that men are masculine and women are feminine. This causes women to be put in the second place and causes women to receive unfair treatment from both the community and men. Aladdin movie could teach viewers that a woman not only becomes a person who accepts, but also has the right to fight for gender equity.

In relation to children's development, children's development cannot be separated from what they have around them. Not only the people around them like parents, friends and teachers but also the media influence their development. Swindler [6] stated that mass media have influencing roles in building beliefs and values: "The accumulated experience [of media exposure] contributes to the cultivation of a child's values, beliefs, dreams, and expectations, which shape the adult identity a child will carry and modify through his or her life" (p. 311). What a child experiences, especially when it really impresses him, will always be remembered and will be able to become part of his personality. There will be a strong attachment that can shape his character as Grossberg et al. [7] said:

"The media have become an inseparable part of people lives, of their sense of who they are and of their sense of history. The media provide an even larger part of the imaginary and soundtrack of people's memories. Some of our most powerful, most intensely emotional and most important moments are intricately bound up with media (p. 31)."

Some of what children watch will leave trails and stay long in their memories. Children are unaware that those things could become values and beliefs that will eventually become their characters.

\section{Research Method}

This research was conducted in the context of gender studies where gender inequity was found in the Aladdin movie. Gender studies claim that relationships based on the identities of man and woman are central [8]. The relationship between women and men causes the division of social roles and activities between women and men governed by an ideology known as patriarchy. Further, Enloe and Cohn [8] noted that it is not men-on-top that makes something patriarchal. It's men who are recognized and claim a certain form of masculinity, for the sake of being more valued, more 'serious', and 'the protectors of/and controllers of those people who 
are less masculine' that makes any organization, any community, any society patriarchal (p. 218).

The method used is descriptive qualitative. With this method, the object of research can be described based on the stated facts. In addition, the method can be used to describe and understand the existence of gender resistance. Data of this study were taken from the Aladdin movie transcript consisting of 58 pages [9]. The source of the data selected in this research is the utterances of the characters that express gender resistance. The analysis is based on the theory of feminist literary criticism. Everywhere patriarchy governs, women are commonly marginalized for their conditions are different from male norms and values. Feminism is a woman's movement to reject everything that is marginalized, subordinated and denigrated by the dominant culture in the political, economic and social life in general. This criticism means reading with awareness to dismantle the presumption and ideology of male patriarchal power. So, the purpose is to make women get the same rights, power and opportunities as men and be treated in the equal ways.

\section{Findings and Discussion}

\subsection{Kinds of Gender Resistance}

From the data presented, there are several kinds of gender resistance found. Those cover almost all aspects of life of the female leading role, Jasmine. Further explanation of the finding is discussed below.

\subsubsection{Resistance to Female Domestication}

Page 8

Jasmine: Agrabah. It's so beautiful. I should get out more.

Jasmine's condition as a woman makes her unable to go free as she wishes. As a woman and at the same time the king's daughter, Jasmine spends much of her time in the palace so she does not know much about the kingdom and the people of her country.

Aladdin: You should tell the princess to get out more. The people haven't seen her in years.

Jasmine: They won't let her. Ever since my... The queen was killed, the sultan's been afraid. So, she's kept locked away.

Jasmine's freedom to go out of the palace is getting smaller because the king remembers what has happened to his wife that is she was murdered. The king's concern for Jasmine arises in case what his mother experienced will also be experienced by Jasmine. The king is worried that as a woman, Jasmine could not maintain her safety. She is considered weak and helpless to face the world outside the palace.

Jasmine: I feel like I'm...Trapped. Like you can't escape. what you were born into?

The situation experienced by Jasmine makes her feel like a prisoner. Jasmine feels that she does not have the freedom she is supposed to get. 


\subsubsection{Resistance to Restrictions on Participating in Public Affairs}

\section{Page 11}

Jasmine: Invade Shirabad? What?

The matter of country security is a problem usually addressed by the king and his advisors. In this case Jasmine feels that she also has the same opportunity to think the best for her country. Her statement of disapproval to attack the other State expresses her opposition to the restrictions placed on her to participate in public affairs in her country.

Jasmine: What foreign prince could care for our people as I do? I could lead if only...

Jasmine feels that she could do the best for her country if she were given the opportunity to be a leader. She feels the other prince would not pay as much attention and care as she has.

Sultan: My dear, you cannot be a sultan... because it has never been done in the 1,000year history of our kingdom.

In fact, his father forbids her to be the leader of the country because the existing tradition states that a woman could not become a leader of the country. The system that applies is a man who can become king.

\section{Page 11}

Jafar: Life will be kinder to you, Princess, once you accept these traditions... and understand it's better for you to be seen and not heard.

The existing system, patriarchy, makes Jasmine lose the opportunity to become the leader of her country. Even, because of her condition as a woman, she is seen as nothing more than an object that can only be seen but cannot state what she is thinking.

Page 11-12

Jasmine: Here comes a wave. Meant to wash me away

That is taking me under

Broken again

Left with nothing to say

My voice drowned out

In the thunder

But I can't cry

And I can't

Start to crumble

Whenever they try

To shut me or cut me down

I can't stay silent

Though they wanna

Keep me quiet

And I tremble

When they try it

All I know is I won't 


\section{Go speechless}

Although Jasmine is a woman, she does not want to accept what the tradition says for her. Jasmine states that she will continue to voice what she feels right. She opposes traditions that forbid women to have equal treatments as men.

Page 13

Jasmine: There has to be something I can do.

The desire to fight against what happens continues to arise in Jasmine. she is determined not to accept anything that she thinks incompatible with justice between women and men.

Dalia: A handsome prince wants to marry you. Oh, when will life gets easier?

Even though, Jasmine gets an offer to live comfortably by marrying a handsome prince, she keeps rejecting it. For her, living comfortably is not to marry a handsome prince but how she gets the freedom to choose and do what she wants.

Jasmine: It's not that I don't want to marry, it's just...

Dalia: You want to be sultan

The demands to her to get married does not lessen her desire to participate in public affairs. Jasmine still thinks more about how to make her people live better than think about marriage.

Jasmine: I can help. I know I can. I was born to do more than marry some useless prince. If you had to marry a useless prince, ....

Jasmine does not want her marriage only for fulfilling the demand that is she has to get married. The marriage she wants is to marry someone who is able to respect herself as a woman who has an equal position as a man, not just as a wife.

Page 38

Jasmine: It's them, the people. They make it beautiful. And they deserve a leader who knows that.

Jasmine's desire to participate in public affairs does not make her lose respect for others. She appreciates others as much as she wants to be appreciated.

Page 39

Jasmine: I don't know why I think it could be me.

Although Jasmine is a woman, she does not feel that she does not have the right to participate in public affairs or in this case to be a leader. She feels she has the same opportunity as a man.

Page 47

Jafar: And understand it's better for you to be seen and not heard. I think we've heard enough from you, Princess. Stay silent. 
The patriarchal hegemony still demands Jasmine to be quiet and accept her condition as a woman. Women are seen as the second class which does not have the right to speak. They can only be seen but do not have the opportunity to participate and involve in public affairs.

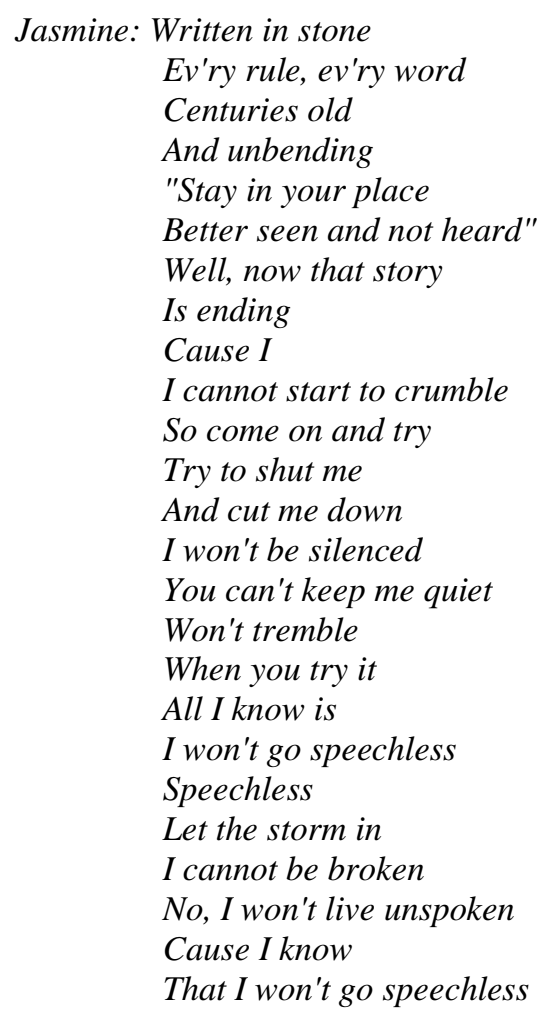

Existing tradition forbids women to participate in activities that are usually carried out by men. Women are only given domestic space limited to giving birth, bringing up children, and doing activities in the kitchen. Other things are men's businesses. Jasmine has opposed these traditions. She feels that a woman should not only accept what is given and what is forbidden for her. She feels that a woman also has the same opportunity to behave as a man does.

Page 48

Jasmine: but it's up to you. Will you stand silent while Jafar destroys our beloved kingdom... or will you do what is right... and stand with the people of Agrabah?

Even though Jasmine is a woman, she believes that she has the right to determine her own destiny. She does not want what happens to her to be a decision taken by someone else. What happens to her is what she decides. Her fate does not depend on what is stated by others.

Page 55

Sultan: not the woman you have become. You have shown me courage and strength. You are the future of Agrabah. You shall be the next sultan. ... And as sultan, you may change the law. 
In the end, what Jasmine fights for is paid off. She receives respect for her efforts to have equity with men. Resistance made against male domination of women makes her receive the highest recognition.

\subsubsection{Resistance to Arranged Marriage}

\section{Page 10}

Jasmine: We have the same title, yet are never described the same way.

Arranged marriage is a form of male domination over a woman. A woman is only considered as an element that can be treated as a man's desire. Jasmine does not approve this condition. She fights against her father's desire to marry the person who proposes her. As a woman, Jasmine cannot accept what is done to her. Instead, she states that the candidate's position and value is not higher than hers.

Jafar: My sultan, our enemies grow stronger every day... yet you allow your daughter to dismiss Prince Anders... and a possible military alliance.

The custom to match women with men who are not their choice is familiar in an area where patriarchal hegemony is very strong. This condition does not make Jasmine willing to accept what is determined for her. Resistance arises from Jasmine by refusing an arranged marriage to her.

Page 30

Jasmine: And what do you hope to buy with this expensive?

Aladdin: You!

Jasmine: Are you suggesting I am for sale?

Arranged marriages by giving valuable items to a woman's family are not unfamiliar to the patriarchal system. By giving away valuables, a man has full rights to the woman. Jasmine does not agree with this custom. She fights back by rejecting the custom. Jasmine wants the matchmaking to occur because she indeed wants it, not because it is determined by others including her father.

\subsubsection{Resistance to The Education Limitation}

\section{Page 11}

Jasmine: I have been preparing for this my whole life. I have read...

Jafar: Books? But you cannot read experience. Inexperience is dangerous.

Education is considered not the main thing for women. When a woman reads a book, it does not mean she is considered to be more knowledgeable and smarter. She is still considered as not having enough knowledge to participate in discussing the things she knows. A man is still considered more knowledgeable because of the experience he has. The male domination states that knowledge is owned by men and remains more dominated by men even though women have received sufficient education. 
Page 37

Jasmine: Maps are how I see the world

Although there are restrictions on her movement, that she must not get out of the palace, Jasmine still wants to know the other world. The thing she does is to read the map. Reading the map gives her knowledge not only about the geographical conditions of her country but also other countries. Reading the map opens her eyes to the world.

\subsection{Resistance Practices}

Unequal gender construction is seen in this Aladdin film. The female character presented by Jasmine is in a subordinate position while the male characters become more powerful roles. On many occasions, the female character does not get enough opportunities not only to participate in public affairs but also in her personal affairs such as marriage. For male characters, the marriage of the female character is not only about personal relationships between individuals who are united in a relationship and commitment but it is also a way to achieve certain political purposes. Respect and appreciation given to women are also so low that it is said that they should be seen but not heard. Mulvey [10] noted that traditionally, women who are shown have functions on two levels: as erotic objects for characters in screen stories, and as erotic objects for spectators in the auditorium. Gender inequity tends to put women in a subordinate place. They exist but they can't speak. Their physical appearance is valued more than their thoughts. Price Anders' utterances in the film (p. 10). 'So, why doesn't anyone tell me about your beauty? You didn't mention your property either' show how the evaluation is given by men to women. Beauty is seen more important than knowledge and ability a woman possesses.

Additionally, the activities carried out by the characters in the film show a more visible unequal gender construction. In several occasions, Jasmine does not have the authority to get out of the palace. The utterances (p. 8): 'Agrabah. That is so beautiful. I have to get out again'.... 'So, she keeps locked up' describe how her movements are restricted. Her opportunity to associate with the world outside the palace is limited since she is a woman. On another occasion, it is described how poor appreciation is given to an educated woman. The conversation between Jasmine and Jafar really shows this matter.

Jasmine: I have prepared this all my life. I have read...

Jafar: Book? But you can't read experiences. Less dangerous experience.

Even though this woman already has enough knowledge, she is still unfit and improper for the public. These things encourage the emergence of resistance to jasmine to get gender equity.

\section{Conclusion}

Watching Movies does not only give entertainment but can also give knowledge and an awareness of a certain theme. Aladdin movie could take the imagination of the viewers to go to Arabian countries, wander to deserts, enjoy the beauty of the Arabian dances, taste Arabian meals and do other activities. This movie truly gives amusement to its viewers. In addition, the viewers, especially children could also learn an unpredictable lesson from the movie. 
The acts of Jasmine, one of the leading roles in the movie, teach how to respond unequal treatments caused by gender inequity. The actions made and the responses given by Jasmine to her position show that it is possible for the dominated to make resistance. It should be realized that the dominant group will always try to maintain its dominance over the weak not only in a certain aspect but, when it is possible, in the entire aspects of life. This dominance has to be understood by the dominated as a control over their lives. If they want to have equal treatment and the same opportunities as the dominating group, they have to make resistance to show that they are not silent party that will accept their lives as they are.

Gender equity in movies may not be clearly exposed. This suggests that movie viewers should be able to watch movies critically to understand the attempts made by the characters to achieve gender equity. Finally, the way in understanding Aladdin movie can also be used to get the message taken in other movies.

\section{References}

[1] The Walt Disney Company, "About," The Walt Disney Company, 2019. [Online]. Available: https://www.thewaltdisneycompany.com.

[2] The Numbers, "Where Data and the Movie Business Meet," The Numbers, 2019. [Online]. Available: https://www.thenumbers.com/movie/Aladdin-(2019)\#tab=summary.

[3] M. C. Alcalde, The woman in the violence: Gender, poverty, and resistance in Peru. Vanderbilt University Press, 2010.

[4] J. H. Mills, A. J. Mills, and R. Thomas, Identity politics at work: Resisting gender, gendering resistance. Routledge, 2004.

[5] E. Sifaki and A. Spiropoulou, "Gender Resistance: Contemporary practices and approaches," Eur. J. English Stud., vol. 16, no. 3, pp. 187-198, 2012.

[6] A. Swidler, "Culture in action: Symbols and strategies," Am. Sociol. Rev., pp. 273-286, 1986.

[7] L. Grossberg, E. Wartella, D. C. Whitney, and J. M. Wise, Mediamaking: Mass media in a popular culture. Sage, 2006.

[8] G. Hoogensen and K. Stuvøy, "Human security, gender and resistance," Secur. Dialogue, vol. 37 , no. 2, pp. 207-228, 2006.

[9] Springfield, "Aladdin Movie Script,” Springfield, 2019. .

[10] L. Mulvey, "Visual pleasure and narrative cinema," Media Cult. Stud. Keyworks, pp. 342-352, 2006. 